Peran Kepemimpinan Kiai Di Pendidikan Pesantren Dalam....

\title{
PERAN KEPEMIMPINAN KIAI DI PENDIDIKAN PESANTREN DALAM MENGHADAPI REVOLUSI INDUSTRI 4.0
}

\author{
Asnawan ${ }^{1}$ \\ Sulaiman ${ }^{2}$ \\ IAI Al-Falah As-sunniyyah Kencong Jember \\ sulaiman_mk@gmail.com
}

\begin{abstract}
This paper discusses the role of the kiai's leadership in pesantren education in an effort to strengthen the Industrial Revolution 4.0 industry. Pesantren is an ideal education system that attempts to provide education to the community to develop the existing potential, because pesantren santri in pesantren are not only given religious knowledge, santri are also taught to live independently, have character and innovate through pesantren activities. The pesantren is one of the institutions of Islamic education that will produce a generation of Indonesians into 'ulama', Muslim scholars and generations who have national character and morality. In the current era of information technology development, learning approaches have experienced rapid development that can change people's mindsets. The availability of information technology that is connected to the internet makes it easy for everyone to access science. So that pesantren must also be able to actualize these developments by developing pesantren curricula that are in accordance with the needs of the times. Then what is the role of pesantren in facing the development of globalization, what strategies are suitable in dealing with generations of the millennial era.
\end{abstract}

Keywords: Role of Kiai, Islamic Boarding School Education, Revolution 4.0

\begin{abstract}
Abstrak
Tulisan ini membahas tentang peran kepemimpinan kiai dalam pendidikan pesantren dalam upaya memperkuat industri Revolusi Industri 4.0. Pesantren merupakan sistem pendidikan yang ideal upaya memberikan pendidikan terhadap masyarakat untuk mengembangkan potensi potensi yang ada, karena dipesantren santri di pesantren tidak hanya diberikan pengetahuan agama saja, santri juga di ajarkan hidup mandiri, berkarakter dan berinovasi melalui kegiatan-kegiatan pesantren. Pesantren menjadi salah satu lembaga pendidikan agama Islam yang akan mencetak generasi Indonesia menjadi ulama' besar, cendikiawa muslim dan juga generasi yang mempunyai karakter kebangsaan dan berakhlakul karimah. Di era perkembanagn teknologi informasi saat ini, pendekatan pembelajaran telah mengalami perkembangan yang sangat cepat sehingga dapat merubah pola pikir masyarakat. Ketersediaan teknologi informasi yang tersambung internet membuat semua orang dengan

\footnotetext{
${ }^{1}$ Dosen IAI Al-Falah As-sunniyyah Kencong Jember

${ }^{2}$ Dosen IAI Al-Falah As-sunniyyah Kencong Jember
}

Falasifa, Vol. 11 Nomor 1 Maret 2020 | 21 


\section{Sulaiman}

mudah untuk melakukan akses keilmuan. Sehingga pesantrenpun juga harus bisa mengaktualisasikan perkembangan tersebut yaitu dengan mengembangkan kurikulum pesantren yang sesuai dengan kebutuhan perkembangan zaman. Lantas bagaimana peran pesantren dalam menghadapi perkembangan globalisasi, strategi apa yang cocok dalam menghadapi generasi era millennial.

Kata Kunci: Peran Kiai, Pendidikan Pesantren, Revolusi 4.0

\section{A. PENDAHULUAN}

Sebagaimana telah kita ketahui bersama bahwa pondok pesantren merupakan lembaga pendidikan tradisional asli Indonesia, yang munculnya bersamaan dengan misi dakwah Islam di kepulauan Melayu - Nusantara sekitar abad 13 dan ada pendapat lain sekitar abad 14. Dan jika kita telusuri perjalanan sejarah pendidikan di Indonesia jauh kemasa lampau, akan sampai pada penemuan sejarah, bahwa pondok pesantren adalah salah satu bentuk peradaban Indonesia yang dibangun sebagai institusi pendidikan keagamaan yang bercorak tradisional, lebih unik dan "Indigenous Culture" atau bentuk kebudayaan asli Indonesia.

Pesantren atau biasa disebut pondok merupaka suatu tempat dimana para santri menggali ilmu agama dan sekaligus pondok menjadi tempat tinggal para santri ${ }^{3}$. Pesantren merupakan salah satu lembaga pendidikan Islam dan dakwah paling mapan, mengakar dan luas penyebarannya ditandai dengan banyaknya Pesantren disetiap daerah di seluruh penjuru Indonesia terutama di Jawa. Dari lembaga inilah Kyai sebagai tulang punggung penyebaran Islam berasal. Corak budaya Islam di Indonesia selama ini menjadi kental oleh nuansa tradisi pesantren. ${ }^{4}$

Secara historis pesantren memiliki peran yang sangat segnfikan dalam proses pembangunan bangsa. Selain sebagai institusi pembentuk kebudayaan Islam pesantren juga punya peran besar. Keberadaanya cukup mengakar di tengah tengah masyarakat. Sebagai agen pencerahan, pesantren juga sebagai agen transformasi kultural di lingkunganya masing-masing.

Pesantren adalah tempat kyai untuk mendidik para santri dan sebagai wadah untuk berdakwah. Dalam rentangan waktu pesantren telah tersebar diseluruh wilayah Indonesia, sebagai lembaga yang sudah bayak berkembang di wilayah kota maupun propinsi di

3 Mujamil Qomar, Pesantren Dari Transpormasi Metodologi Menuju Demokratisasi Institusi (Jakarta: Erlangga, 1996), 2

${ }^{4}$ Zamakhsyari Dhofier, Tradisi Pesantren Studi tentang Pandangan Hidup Kyai (Jakarta : LP3ES, 1982), 50

22 | Falasifa, Vol. 11 Nomor 1 Maret 2020 
Nusantara. Pesantren merupakan lembaga yang bersifat religus karena didalam pesantren para santri diberi pelajaran oleh kyainya tentang apapun yang diajarkan oleh islam. Dan juga didalam pesantren para kyai memberi pelajaran seperti apa yang di ajarkan oleh para wali-wali yang ada di Indonesia contoh salah satunya yaitu bejar kitab kuning (kitab gundul). Jadi kehadiran pondok pesantren secara jelas dan nyata telah membantu pemerintah dalam rangka mencerdaskan kehidupan bangsa.

Elemen terpenting dalam pesantren adalah keberadaan kyai. Kyai istilah lain dari kata Ulama, namun orang Jawa dan Madura khususnya sering mengistilahkan atau menyebut orang yang mengasuh Pondok Pesantren sangat mendalam ilmu agama (Islam) adalah Kyai. Sebagian besar Pondok Pesantren di daerah Jawa dan Madura sosok Kyai merupakan sosok yang sangat berpengaruh, kharismatik, berwibawa dan peduli dengan derita umatnya. Selain kriteria tersebut Kyai sebagian besar di daerah Jawa dan Madura adalah pendiri dari Pondok Pesantren yang berada ditengah-tengah masyarakat. Maka tak heran sosok Kyai di masyarakat sangat dihormati, dikagumi dan dicintai oleh masyarakat. Hal ini terjadi karena tidak sedikit para Kyai selalu peduli, bermasyarakat dan memperhatikan umat atau rakyat kecil. ${ }^{5}$

Kyai berperan sebagai tokoh sentral dan pemandu kebijakan tertinggi yang mana dijadikan panutan oleh para santri dalam kehidupan kesehariannya baik dari prilaku, sikap dan kepribadiannya. kiai juga memiliki kearifan yang tercermin dalam sikapnya yang slalu meresponden, dan menyejukkan dalalm berbagai persoalan. Kiai memiliki kemamapuan untuk mendialogkan prinsip-prinsip ajaran islam dengan realitas kehidupan sehari-hari. kiai slalu memberikan solusi alternativ dalam menyelesikan suatu persoalan. Dawuh atau katakata seorang kyai (pada masa penyebaran islam) adalah nasehat yang akan cepat diterima oleh masyarakat. Kyai mempunyai kemampuan dalam bidang agama dan ilmu kehidupan social lainnya. Dan sampai saat ini citra dan charisma seorang kyai terus kuat ditengahtengah masyarakat. ${ }^{6}$

Dalam sejarahnya, perkembangan pesantren di Indonesia sangatlah pesat, mereka mampu mengikuti perkembangan zaman dengan tantangan-tantangan yang dapat merubah ruang lingkup kemasyarakatan. Secara fundamental, era globalisasi teknologi ini akan

\footnotetext{
${ }^{5}$ Dhofir, Tradisi Pesantren, 59

${ }^{6}$ Zaitur Rahem, Jejak Intelektual Pendidikan Islam; Generasi Salafiyah dan Khalafiyah, (Yogyakarta: Pustaka IImu, 2016) 51
}

Falasifa, Vol. 11 Nomor 1 Maret 2020 | 23 


\section{Sulaiman}

merubah cara hidup manusia baik dalam style dan ataupun pola hidup mereka. Sehingga pesantren juga harus mampu beradaptasi dengan dunia digital, dunia dimana manusia diidentikkan dengan teknologi informasi. Perkembangan dan kemajuan dunia teknologi informasi juga akan membawa perubahan radikal disemua dimensi kehidupan manusia. Era perkembangan Revolusi Industri 4.0 (RI 4.0) membawa kehidupan manusia dalam kehidupan yang baru terutama dalam manufaktur dan teknologi industri. Perkembangan RI 4.0 tersebut ditandai dengan pemanfaat teknologi informasi berbasis internet. Perkembangan teknologi informasi berkembang sangat masif, dimana manusia bisa menggunakan media informasi secara bebas.

Generasi gudget atau biasa disebut generasi millenial marupakan generasi yang lahir di tahun 2000 an. Mark dalam tulisannya Gazali menyebutkan bahwa generasi yang lahir di tahun tersebut adalah generasi Alfa ${ }^{7}$.

Secara karakteristik, generasi alfa adalah generasi yang ketika lahir sudah mengenal dengan teknologi industri, dimana teknologi berada dalam kecerdasan yang tinggi. Sehingga anak yang lahir di tahun tersebut mengakibatkan akan mempunyai dunia baru, mereka akan lebih banyak bermain, belajar secara mandiri dan juga dapat melakukan interaksi dengan dunia global melalui dunianya sendiri. Pada akhirnya ketika mereka dewasa, teknologi informasi akan menjadi dari hidup mereka dan bahkan menjadikan seperti halnya seorang kekasih. Generasi ini sangat berbeda dengan generasi sebelumnya, karena dengan perkembangan teknologi informasi, mereka akan dapat membentuk kepribadian dan sikap mereka.

Berdasarkan uraian di atas, maka timbul pertanyaan besar; apakah pendidikan pesantren di era millenial mampu menghadapi perubahan RI 4.0 dan bagaimana respon pesantren dalam menjawab tantangan perkembangan teknologi informasi, apakah santri di era RI 4.0 mampu beradaptasi dengan dunia luar yang serba digital, bagaimana karakteristik santri untuk mengembangkan kompetensi mereka dalam menghadapi perkembangan RI 4.0.

\section{B. PEMBAHASAN}

\section{Pengertian dan Sejarah Pesantren}

${ }^{7}$ Gazali, E. (2018). Pesantren di antara generasi alfa dan tantangan dunia pendidikan era revolusi industri 4.0. OASIS : Jurnal IImiah Kajian Islam, 2(2), 94-109.

24 | Falasifa, Vol. 11 Nomor 1 Maret 2020 


\section{Peran Kepemimpinan Kiai Di Pendidikan Pesantren Dalam....}

Pondok pesantren adalah gabungan antara kalimat pondok dan pesantren. Istilah pondok berasal dari kata funduk, dari bahasa arab yang berarti rumah penginapan atau hotel, akan tetapi dalam ke-pesantren-an Indonesia, khususnya pulau Jawa, lebih mirip dengan pemondokan dalam lingkungan padepokan, yaitu perumahan sederhana yang dipetak-petak dalam bentuk kamar-kamar yang merupakan asrama bagi santri. Istilah pesantren bisa disebut dengan pondok saja, pesanten saja atau digabungkan menjadi sebutan pondok pesantren yang maksud sama, namun pembedaannya adalah asramanya dan santri yang menempati asram tersebut, maksudnya pesantren yang santrinya tidak mnetap diasrama, melainkan mereka tinggal di desa sekitar pesantren yang biasa disebut dengan santri kalong mereka menimba ilmu agama dipesantren. ${ }^{8}$

Sedangkan istilah pesantren secara etimologi berarti pe-santrian yang berarti tempat santri, pondok pesantren adalah lembaga keagamaan yang memberikan pendidikan dan pengajaran serta mengembangkan dan menyebarkan ilmu Agama Islam. Pesantren disebut pondok pesantren atau pendidikan tradisional, sekalipun sudah banyak pessantren modern, merupakan lembaga pendidikan Islam tertua di indonesia.

Menurut Muhaimin dan Abdul Jalal pondok pesantren yaitu lembaga pendidikan Islam yang didalamnya terdapat kyai (pendidik) yang mengajar dan mendidik para santri (anak didik) dengan sarana masjid yang digunakan untuk mnyelenggarakan pendidikan tersebut, serta didukung adanya pondok atau bangunan sebagai tempat tinggal para santri dan mempelajari kitab kuning. ${ }^{9}$

Jadi, pondok pesantren adalah lembaga pendidikan yang bernafaskan Islam unruk memahami, menghayati, mengamalkan ajaran Islam (Tafaqquh fiddien) dengan menekankan moral Agama pedoman hidup bermasyarakat, yang didalamnya mengandung beberapa elemen yang tidak bisa dipisahkan, yang diantara lain kyai sebagai pengasuh sekaligus pendidik, masjid sebagai sarana peribadatan sekaligus berfungsi sebagai tempat pendidikan para santri dan asrama sebagai tempat tinggal.

\footnotetext{
${ }^{8}$ Mujamil Qomar, Pesantren: Dari Transformasi, Metodelogi Menuju Demokratisasi Institusi (Jakarta: Erlangga, 2003), 1

${ }^{9}$ Muhaimin \& Abdul Mujib, Pemikiran Pendidikan Islam: Kajian Filosofik dan Kerangka Operasionalnya (Bandung: Trigenda Karya, 1993), 298-299
} 
Sedangkan Pondok Pesantren tumbuh dan berkembang sekitar abad ke 13 sampai ke 19 M. yaitu setelah islamisasi mencapai tahap pribumisasi. Berkembang ang penulis maksudkan, rub pesantren sudah menyebar kepelosok nusantara. Pergerakan pondok pesantren tidak bisa lepas dari proses islamisasi di Indonesia. Akan tetapi, sejumlah kajian ilmu keislaman Indonesia, mengidentikkan pondok pesantren dengan islami pada masa kerajaan. Islam tersebar di Indonesia bisa dikategorikan ke dalam tiga masa. Yaitu, masa kerajaan, masa muballigh dan masa santri. Pada masa kerajaan, islamisasi lebih banyak dilakukan untuk mengajak sejumlah raja-raja yang pada awalnya menganut agama hindu dan budha untuk memeluk agama islam. Pada masa kerajaan ini kiprah para wali songo di pulau jaawa banyak dibahas dalam kajian sejarah islamisasi di indonesia. Bahkan, istilah pesantren menjadi istilah baku yang dipergunakan untuk memfasilitasi lembaga pendidikan keislaman yang memiliki variabel masjid, santri, kyai, dan proses pengajaran keislaman. ${ }^{10}$

Pesantren adalah lembaga pendidikan islam tertua di indonesia. Lembaga pendidikan ini pertama kali didirikan oleh maulana malik ibrohim atau Gresik. Kemudian sunan Ampel juga mendirikan pondok pesantren di kembang kuning Ampel Denta Surabaya. Para santri sunan Ampel seperti sunan Giri juga mendirikan pesantren si desa Sidomukti, Gersik yang kemudian terkenal dengan sebutan "Giri Kedaton". 11

\section{Peran kepempinan kiai di Pesantren}

Dalam kepemimpinan pondok pesantren tidak lepas dari kiai sebagai pemangku kekuasaan tertinggi tentu mempunyai peran yang sangat signifikan yakni diantaranya;

a) Pengasuh

Kyai sebagaimana penulis sebutkan diatas bahwa seorang kyai sebagai pemangku kebijakan dalam sebuah pondok pesantren, tentu seorang kyai sebagai pemimpin dalam pesantren. Ditinjau dari corak konteks sosial, ada 3 tipologi kepemimpinan kyai sebagaimana pendapat Waber yang dikutip oleh Moh. Ali Aziz yaitu; pertama, kepemimpinan kharismatik yang pengabsahannnya berasal

${ }^{10}$ Zaitur Rahem, Jejak Intelektual Pendidikan Islam, 57

${ }^{11}$ A. Jauhari Fuad dkk, Waspada! Penetrasi Neo-Salafi Wahabi di Madrasah NU (Sidoarjo: Al-Maktab, 2015), 48

26 | Falasifa, Vol. 11 Nomor 1 Maret 2020 
Peran Kepemimpinan Kiai Di Pendidikan Pesantren Dalam....

dari kekuatan adikodrati. Kedua, kepemimpinan tradisonal yang pengabsahannya berasal dari keturunan dari kyai sebelumnya. Ketiga, kepemimpinan legal formal yaitu kepemimpina yang pengabsahannya berasal dari aturan yang berlaku. Dalam sebuah pesantren kepemimpinan kyai sangat berpengaruh dan sangat menentukan perkembangan pesantren yang dipimpinnya.

b) Kyai sebagai guru pendidik utama

Kyai dikenal sebagai gruru pendidik utama dalam sebuah pesantren karena kyailah yang selalu memberikan bimbingan, pengarahan dan pendidikan kepada santri-santrinya. ${ }^{12}$

Mengajar dan mendidik menjadi tugas utana kyai di pondok pesantren untuk memberikan pemahaman nilai-nilai ajaran agama islam kepada santrinya dan diimplementasikan dalam kehidupan sehari-hari.

c) Penggerak pesantren

Kyai didalam dunia pesantren tentu sebagai penggerak dalam mengemban dan mengembangkan pesantren. Kyai bukan hanya memimpin dan pengasuh pondok pesantren tetapi juga pemilik pondok pesantren.

Dengan demikian kemajuan dan kemunduran pondok pesantren benartbenar terletak pada kemampuan kyai dalam mengatur operasionalisasi / pelaksanaan pendidikan dalam pesantren, sebab kyai merupakn penguasa baik dalam pengertian fisik maupun non fisikyang bertanggung jawab demi kemajuan pesantren. Dalam kenyataannya pesantren sebagian besar berkembang dan menemukan bentuknya yang lebih mapan. Faktyorm utamanya adalah karena adanya kyai yang selalu teratanam rasa memiliki, bahkan tidak jarang berdirinya suatu pondok pesantren merupakan gagasan dalam diri kyai, sekalipun sekarang banyak yang berasal dari masyarakat. ${ }^{13}$

d) Figur dan kekuatan moral (moral force)

\footnotetext{
${ }^{12}$ Gunawan \& Ali Hasan Siswanto, Islam Nusantara dan Kepesantrenan, 163

${ }^{13}$ M. Bahri Ghazali, Pesantren Berwawasan Lingkungan (Jakarta: Prasasti, 2002), 21-22
}

Falasifa, Vol. 11 Nomor 1 Maret 2020 | 27 
Muhammad Idris jauhari berpendapat bahwa kyai befungsi sebgai moral force bagi para santri dan seluruh penghuni pesantren, dimana antara santri dan kyai tercipta hubungan batin (bukan sekedar emosional) yang tulus dan kokoh, bahkan sampai ketika mereka pulang kemasyarakat. Inilah suatu kondisi yang seharusnya terdapat dalam lembaga pendidikan apapun, tetapi sangat jarang temukan-kalau tidak akan disebut tidak ada -dalam sistem-sistem pendidikan lainnya. ${ }^{14}$

Juga, dalam tradisi pesantren kyai tetap merupakan figur yang ditaati oleh para santri, guru, pengurus dan staff atau pembantu dalam menyelesaikan tugastugas dikalangan pesantren. Kefiguran kyai sangatlah tergantung kepada kemampuan, ketinggian ilmunya dan kewibawaannya sebagai kyai. ${ }^{15}$

e) Teladan

Kyai sebagai pendidik membeikan keteladanan kepribadian muslim dalam segala aspek kepada santrinya, baik dalam aspek vertikal Hamblum Minallab (cara kita berkomunikasi baik dengan Allah SWT.), maupun horizontal (hubungan kita sesama manusia maupun kepada alam). Dalam Islam bahkan peneladanan ini sangat diistimewakan dengan menyebut Nabi Muhammad Saw. adalah teladan yang baik (uswatun hasanah). ${ }^{16}$

\section{Revolusi Industri 4.0}

Definisi tentang revolusi industry 4.0 sangatlah beragam karana masih dalam tahap penelitian dan pengembangan. Kanselir jerman berpendapat bahwa industry 4.0 adalah tranformasi komprehenshif dari kesuluruhan aspek produksi diindustri melalui penggabungan teknologi digital dan internet dengan industri konvensional. ${ }^{17}$

\footnotetext{
${ }^{14}$ Muhammad Idris Jauhari, Sistem Pendidikan Pesantren ( Sumenep: Al-Amin Printing, 2002), 25

${ }^{15}$ Gunawan \& Ali Hasan Siswanto, Islam Nusantara dan Kepesantrenan, 165

${ }^{16}$ Ahmad Royani, Desain Pembelajaran Berbasis Berbasis Budaya dan Nilai (Jember: Stain Jember Press, 2014), 69

${ }^{17}$ A. Markel. Speech by Federal Chancellor Angela Markel to the OECD Conference.

28 | Falasifa, Vol. 11 Nomor 1 Maret 2020
} 
Sementara Schlechtendhal dkk menekankan definisi industry 4.0 terhadap unsurunsur kecepatan dari ketersediaan informasi dari satu dengan yang lainnya. ${ }^{18}$

Pengertian lain yang lebih kepada teknis sebagaimana disampaikan oleh kagermaan dkk, bahwa Industri 4.0 adalah integrasi dari Cyber Physical System (CPS) dan Internet of Things and Services (IoT dan IoS) ke dalam proses industri meliputi manufaktur dan logistik serta proses lainnya. CPS adalah teknologi untuk menggabungkan antara dunia nyata dengan dunia maya. Penggabungan ini dapat terwujud melalui integrasi antara proses fisik dan komputasi (teknologi embedded computers dan jaringan) secara close loop ${ }^{19}$. Juga ditambahkan oleh herman dkk bahwa Industri 4.0 adalah istilah untuk menyebut sekumpulan teknologi dan organisasi rantai nilai berupa Smart Factory, CPS, IoT dan IoS. Smart factory adalah pabrik modular dengan teknologi CPS yang memonitor proses fisik produksi kemudian menampilkannya secara virtual dan melakukan desentralisasi pengambilan keputusan. Melalui IoT, CPS mampu saling berkomunikasi dan bekerja sama secara real time termasuk dengan manusia ${ }^{20}$. IoS adalah semua aplikasi layanan yang dapat dimanfaatkan oleh setiap pemangku kepentingan baik secara internal maupun antar organisasi. Terdapat enam prinsip desain Industri 4.0 yaitu interoperability, virtualisasi, desentralisasi, kemampuan real time, berorientasi layanan dan bersifat modular. Berdasar beberapa penjelasan di atas, Industri 4.0 dapat diartikan sebagai era industri di mana seluruh entitas yang ada di dalamnya dapat saling berkomunikasi secara real time kapan saja dengan berlandaskan pemanfaatan teknologi internet dan CPS guna mencapai tujuan tercapainya kreasi nilai baru ataupun optimasi nilai yang sudah ada dari setiap proses di industri.

Jadi di era ini sangatlah mengalami perubahan yang sangat pesat dan sangat cepat. Semua orang dapat dengan mudah menyerap dan menyampaikan informasi melaluli internet.

\footnotetext{
${ }^{18}$ Schlechtendahl, ,dkk. Making existing production systems Industry 4.0-ready. (Production Engineering, Vol. 9, Issue.1. 2015), 143-148.

${ }^{19}$ Lee, E.A. Cyber physical systems: Design challenges. In Object Oriented Real-Time Distributed Computing (ISORC), (IEEE International Symposium: 2008), 363-369.

${ }^{20}$ Hermann, M., Pentek, T., \& Otto, B. (2016). Design principles for industrie 4.0 scenarios. System Sciences (HICSS), 49th Hawaii International Conference, pp. 3928-3937.
}

Falasifa, Vol. 11 Nomor 1 Maret 2020 | 29 


\section{Pesantren dalam Menghadapi Revolusi Industri 4.0}

Pesantren seperti yang kita ketahui bersama bahwa pesantren selalu bersikap sederhana, bahkan santrinya pun di tuntut untuk sederhana. disebagian besar peraturan pondok pesantren dilarang menggunakan hp, gedjet dan yang berbau teknologi lainnya. Lalu bagaimana kira-kira pesantren dan para santrinya untuk menghadapi zaman dimana dipenuhi dengan teknologi dan kecepatan informasi.

Akan tetapi pesantren dan santri akan tetap kuat dan bisa beradaptasi karena punya semboyan (memelihara tradisi lama yang baik dan bertransformasi dengan tradisi baru yang lebih baik) Kutipan kalimat diatas adalah semboyan yang selalu diucapkan dan dijadikan pegangan oleh pesantren di Indonesia. Kalimat tersebut memberi pemahaman bahwa pesantren selalu melestarikan budaya atau metogologi lama yang masih relevan akan tetapi juga melakukan terobosan/langkah/metodologi baru yang inovatif. Pendidikan pesantren sangatlah berbeda dengan pendidikan formal yang ada diluar pesantren, baik dalam kurikulum dan program-progam pesantren. Sebagai contoh "sorogan", dimana santri melakukan pembelajaran secara langsung dan individu dengan guru/kyai mereka, sehingga seorang kyai dapat melakukan evaluasi perkembangan santri secara langsung.

Pendidikan pesantren bertujuan untuk mencetak kader-kader bangsa yang alim, saleh dan kafi, kader bangsa yang mempunyai keilmuan tinggi yang utuh, unggul dan juga berkemajuan. Alim berarti mereka mempunyai knowledge yang mumpuni baik dari keilmuan umum yang dberkembang dan juga ilmu agaman untuk membentengi mereka agar tidak terjebak dalam perkembangan teknologi informasi saat ini. agar kader bangsa bisa kuat dalam baik lahir dan batin mereka maka mereka juga harus bisa menjadi orang saleh, orang yang mempunyai kekuatan bathiniyah yang kuat dengan penciptanya agar terjaga dari hal-hal yang negatif menurut kalayak umum. Kemudian keder Bangsa akan menjadi manusia yang berkecukupan baik secara ekonomi, hubungan sosial dan juga kedekatan diri mereka dengan pencipta. Akhirnya apabila hal tersebut bisa dilaksanakan dengan baik maka bangsa Indonesai akan mempunyai sumberdaya yang kompeten dan berdaya saing global, tidak akan ada lagi yang namanya kesenjangan sosial diantara mereka.

kalau melihat pengaruh perkembangan industi 4.0, pesantren mau tidak mau juga harus lebih serius lagi dalam mengatasi persolalan Bangsa dalam mencetak 30 | Falasifa, Vol. 11 Nomor 1 Maret 2020 


\section{Peran Kepemimpinan Kiai Di Pendidikan Pesantren Dalam....}

sumberdaya manusia yang kompeten. Manusia yang kompeten adalah mereka yang mempunyai keilmuan luas, kemampuan serta pengalaman yang cukup dalam bidangnya.

Merespon tantangan dan perkembangan teknologi industri dan informasi saat ini, pesantren harus melakukan evaluasi dan juga pengembangan yang secara implisit dapat mengakomodir harapan masyarakat. Ambisi masyarakat terhadap putra-putinya adalah mempunyai moral yang baik ${ }^{21}$. Masyarakat menginginkan agar putra-putinya mempunyai personaliti dan juga etika serta moral yang baik. Menutut Azra \& Afrianty bahwa harapan masyarakat terhadap pesantren yaitu; pertama, secara keseluruhan pesantren harus tetap menjalankan peran mereka dalam transmisi ilmu pengetauan, menjaga tradisi dan juga mencetak calon-calon ulamak dunia. Kedua, santri tidak hanya dibekali ilmu-ilmu agama, akan tetapi jgaa ilmu umum tentang perkembangan pendidikan dunia. Ketiga, santri dibekali ilmu pengetahuan dan keterampilan sesuai dengan minat serta bakat mereka. Agar santri juga mempunyai keahlian dalam bidang teknologi dan sains, yang saat ini menjadi karakter dan ciri perkembangan teknologi, suapaya mereka nantinya dapat bekerja atau membuka lapangan pekerjaan sesuai dengan tuntutan dunia. ${ }^{22}$

Pesantren saat in harus dapat menghadapi tantangan global yaitu dengan menghadirkan program-program yang realistis bagi masyarakat. Ada beberapa prinsip stratgis dalam mengembangkan pendidikan pesantren, antara lain; pertama, pesantren harus lebih serius dalam berorientasi untuk pengembangan sumber daya manusia, sehingga pesantren berfungsi sebagai anticipatory learning institution dengan ketersediaan sumberdaya manusia yang tangguh, manusia yang unggul dan utuh, agar mereka bisa menjadi generasi Bangsa yang cerdas, disiplin, jujur, tekun, ulet dan juga inovatif. Kedua pesantren harus mengarahkan perkembangannya dalam wujud pendidikan yang multikulturalisme. Karena bangsa Indonesia adalah Bangsa yang majemuk, maka pesantren bisa mengemas sistem pendidikannya dalam watak multikultural yaitu pendidikan yang ramah dengan sesama dalam perbedaan budaya, sosial dan juga agama.

\footnotetext{
${ }^{21}$ Nucci, L., Narvaez, D., \& Krettenauer, T. (2013). Handbook of Moral and Character Education. (L. Nucci, D. Narvaez, \& T. Krettenauer, Eds.)

${ }^{22}$ Azra, A., \& Afrianty, D. (2005). Pesantren and Madrasa: Modernity and Indonesian Muslim Society. Workshop on Madrasa, Modernity and Islamic Education May 6-7, 1-31.

Falasifa, Vol. 11 Nomor 1 Maret 2020 | 31
} 
Sampai dekade ini sudah banyak pesantren yang merespon perkembanagn teknologi saat ini, seperti Mambaus Sholihin Gresik, Pesantren Bumi Solawat Sidoarjo, Amanatul Ummah Surabaya, Tebuireng Jombang dan juga berbagai pesantren yang sudah menstransformasi pendidikan agama dengan dunia teknologi, baik dalam pembukaan kelas internasional, progessive, trans science dan ataupun yang lainnya. Pembukaan program tersebut tidak lain inging mencetak kader Bangsa yang mempunyai daya saing global. Salah satu contoh dari beberapa pesantren tersebut adalah Bumi Sholawat Sidoarjo. Pesantren yang terbilag sudah separoh abad ini, bisa melakukan transformasi pendidikan pesantren dengan pendidikan nasional, yaitu di bukanya kelas Progressive. di pesantren ini pembelajarannya sudah memanfaatkan teknologi informasi berbasis online. Selain itu, santri juga diajari tentang perkembanagn teknologi sehingga banyak dari santri sana yang mendapat juara robotik baik Nasional maupun Internasional.

Selama ini pesantren telah banyak mendapat kritikan dari pengamat pendidikan karena masih melakukan proses pendidikan yang eksklusif, domatik dan kurang menyentuh dalam aspek pekembangan teknologi. Akan tetapi kritikan tersebut telah dijawab oleh pendidikan pesantren dalam mencetak kader bangsa yang berwawasan luas dan juga mempunyai moralitas. Hal itu dikarenakan pesantren akan tetap berpegang teguh pada karakter pesantren yaitu "menjaga tradisi yang klasik dan mampu bertranformasi dengan hal baru yang bermanfaat"

\section{PENUTUP/KESIMPULAN}

Pesantren adalah lembaga pendidikan yang bernafaskan Islam unruk memahami, menghayati, mengamalkan ajaran Islam (Tafaqqub fiddien) dengan menekankan moral Agama pedoman hidup bermasyarakat, yang didalamnya mengandung beberapa elemen yang tidak bisa dipisahkan, yang diantara lain kyai sebagai pengasuh sekaligus pendidik, masjid sebagai sarana peribadatan sekaligus berfungsi sebagai tempat pendidikan para santri dan asrama sebagai tempat tinggal. Dan kiai mempunya peran penting/sentral dalam sebuah pesantren karena kiai sebagai pemangku kebijakan tertinggi.

Adapun peran pemangku kekuasaan tertinggi (kiai) yaitu sebagai pengasuh, pendidik utama, penggerak pesantren, figur utama dan teladan. Sehingga perkembangan pesantren sangatlah ditentukan oleh kiainya sendiri.

32 | Falasifa, Vol. 11 Nomor 1 Maret 2020 
Peran Kepemimpinan Kiai Di Pendidikan Pesantren Dalam....

Revolusi Industry 4.0 adalah tranformasi komprehenshif dari kesuluruhan aspek produksi diindustri melalui penggabungan teknologi digital dan internet dengan industri konvensional. Sehingga di era ini akan terjadi banyak perubahan dengan pesat dan lekasnya informasi yang didapatkan melalui teknologi dan internet.

\section{DAFTAR PUSTAKA}

Azra, A. \& Afrianty, D. Pesantren and Madrasa: Modernity and Indonesian Muslim Society. (Workshop on Madrasa, Modernity and Islamic Education. 2005)

Bahri, M. Ghazali, Pesantren Berwawasan Lingkungan (Jakarta: Prasasti, 2002)

Dhofier, Zamakhsyari. Tradisi Pesantren Studi tentang Pandangan Hidup Kyai Jakarta : LP3ES, 1982)

Gazali, E. Pesantren di antara generasi alfa dan tantangan dunia pendidikan era revolusi industri 4.0.

(OASIS : Jurnal Ilmiah Kajian Islam. 2018)

Gunawan \& Ali Hasan Siswanto. 2016. Islam Nusantara dan Kepesantrenan. Yogyakarta: Interpena Yogyakarta

Hermann, M., Pentek, T., \& Otto, B. Design principles for industrie 4.0 scenarios. System Sciences (HICSS: Hawaii International Conference. 2016).

Jauhari, A. Fuad dkk, Waspada! Penetrasi Neo-Salafi Wahabi di Madrasah NU (Sidoarjo: AlMaktab, 2015)

Jauhari, Muhammad Idris. Sistem Pendidikan Pesantren ( Sumenep: Al-Amin Printing, 2002)

Lee, E.A. Cyber physical systems: Design challenges. In Object Oriented Real-Time Distributed Computing (ISORC), (IEEE International Symposium: 2008).

Markel. A. Speech by Federal Chancellor Angela Markel to the OECD Conference.

Muhaimin \& Abdul Mujib, Pemikiran Pendidikan Islam: Kajian Filosofik dan Kerangka Operasionalnya (Bandung: Trigenda Karya, 1993), 298-299

Nucci, L., Narvaez, D., \& Krettenauer, T. (2013). Handbook of Moral and Character Education. (L. Nucci, D. Narvaez, \& T. Krettenauer, Eds.)

Qomar, Mujamil. Pesantren Dari Transpormasi Metodologi Menuju Demokratisasi Institusi (Jakarta: Erlangga, 1996) 
Sulaiman

Qomar, Mujamil. Pesantren: Dari Transformasi, Metodelogi Menuju Demokratisasi Institusi (Jakarta: Erlangga, 2003)

Rahem, Zaitur. Jejak Intelektual Pendidikan Islam; Generasi Salafiyah dan Khalafiyah, (Yogyakarta: Pustaka Ilmu, 2016) 51

Royani, Ahmad. Desain Pembelajaran Berbasis Berbasis Budaya dan Nilai (Jember: Stain Jember Press, 2014)

Schlechtendahl, ,dkk. Making existing production systems Industry 4.0-ready. (Production Engineering, Vol. 9, Issue.1. 2015) 